\title{
GOING ONLINE - IS THE WORLD READY TO REPLACE LITIGATION WITH ONLINE DISPUTE RESOLUTION MECHANISMS?
}

\section{BARTOSZ ZIEMBLICKI*}

\section{INTRODUCTION}

The World Wide Web (www) was invented in $1989^{1}$ and in 1992 an online commerce ban was levied. ${ }^{2}$ The Internet has forever changed peoples' conceptions of human interaction. ${ }^{3}$ Modern societies have moved step-bystep onto the Internet. People not only communicate online, search for information online, purchase online, do business online, and work online, but they also conduct their social lives using online social networking.

E-commerce has blossomed, and more and more deals are struck via the Internet every year. A few examples of this process are provided below. Between March 1999 and March 2000 the number of items for sale on eBay increased from 1.7 million to 4.1 million. ${ }^{4}$ The number of domain names went from 2 million in 1997 to over 30 million in $2001 .^{5}$ The value of e-commerce in the United States alone grew from 33 billion dollars in 1999 to 182 billion dollars in 2009. At the same time, Internet usage expanded from $36.6 \%$ of the

DOI: $10.1515 /$ wrlae-2015-0034

* PhD in International and European Law, Master in Economics, Assistant Professor at the Wroclaw University of Economics, attorney at law and tax advisor at ZKZ Law Firm.

${ }^{1}$ See T Berners-Lee, M Fischetti, Weaving the Web: the Original Design and Ultimate Destiny of the World Wide Web (San Fransisco 1999).

${ }^{2}$ See JP Kesna, RC Shah, 'Fool us once shame on you - fool us twice shame on us: what we can learn from the Privatisations of the Internet Backbone Network and the Domain Name System' (1994) 79(1) Washington University Law Quarterly 91, 113.

${ }^{3}$ L Del Duca, C Rule, Z Loebl, 'Facilitating Expansion of Cross-Border E-Commerce Developing Global Online Dospute Resolution System (Lessons Derived from Existing ODF Systems - Work of the United Nations Commission on International Trade Law)' (2012) 1(1) Penn State Journal of Law \& International Affairs 59.

${ }^{4}$ E Katsh, 'Online Dispute Resolution: Some Lesson from the E-Commerce Revolution' (2001) 28(4) Northern Kentucky Law Review 810.

5 ibid. 
American population to $78.1 \% .{ }^{6}$ In $2007,27 \%$ of individuals in the European Union bought goods or services for private use over the Internet, while in 2014 this number was $41 \%$ (in Poland the increase in the same time was from $11 \%$ to $24 \%)^{7}$

As Ethan Katsh put it, cyberspace is not a harmonious place. It is an environment with an extraordinarily high level of activity, energy, competition and innovation. ${ }^{8}$ No wonder it generates a great number of disputes to resolve. Traditional courts and laws are ill-equipped to handle the unique issues that arise in cyberspace. ${ }^{9}$ State court litigation is obsolete. It has its traditional weaknesses, such as that it is very lengthy and expensive, but it also does not suit e-commerce disputes very well due to jurisdiction issues and the potential geographical distance between parties. For these reasons people are seeking alternatives.

ADR stands for alternative dispute resolution. Alternative because state court litigation is considered to be the primary, default venue. The rationales behind using ADR include caseload reduction of overburdened courts, reduction of expense and delays from traditional litigation, and providing an alternative to those who are disenchanted with the adversarial model of litigation. ${ }^{10}$ ADR is considered more solution-oriented than blameoriented. It consists not only of arbitration, as mediation has in recent years increased in popularity, first in the United States, then later in the European Union as well. ${ }^{11}$

While ADR stands for alternative dispute resolution, ODR stands for online dispute resolution. Some authors call it $\mathrm{OADR}^{12}$ (online alternative dispute resolution), but they are in the minority. Initially ODR attracted the interest of academics more than of practitioners. ${ }^{13}$ There are even international competitions in online dispute resolution held for law students worldwide. $^{14}$ As discussed below, the commercial use of ODR has encountered hurdles. What is striking is that among ODR mechanisms, nonbinding forms have played the lead role so far. For example, the eBay ODR

\footnotetext{
${ }^{6}$ Del Duca, Rule, Loebl (n 3$) 61$.

${ }^{7}<$ http://ec.europa.eu/eurostat $/ \operatorname{tgm} /$ table.do? $\mathrm{tab}=$ table\&init $=1 \&$ language $=$ en $\&$ pcode $=\operatorname{tin} 000$ 67\&plugin=1 $>$ accessed 1 October 2015.

${ }^{8}$ Katsh, 'Online Dispute Resolution (n 4) 811.

${ }^{9}$ MA Geist, 'The Reality Bytes: Regulating Economic Activity in the Age of the Internet' (1998) 73 Washington Law Review 521, 533.

${ }^{10}$ JB Weinstein, 'Some Benefits and Risks of Privatization of Justice Through ADR' (1996) 11 Ohio State Journal on Dispute Resolution 241, 264, 275, 277.

${ }^{11}$ RI Turner, 'Alternative Dispute Resolution in Cyberspace: there is more on the line than just getting "online"” (2000) 7 ILSA Journal of International \& Comparative Law 133, 135136.

${ }^{12}$ HA Haloush, 'The Authenticity of Online Alternative Dispute Resolution Proceedings' (2008) 25(3) Journal of International Arbitration 355, 355; LQ Hang, 'Online Dispute Resolution Systems: The Future of Cyberspace Law' (2001) 41(3) Santa Clara Law Review 837, 838.

${ }^{13}$ T Schultz, 'The Role of Dispute Settlement and ODR' in A Ingez-Housz, ADR in Business: Practice and Issues across Countries and Cultures, vol. II (Bedfordshire 2011) 135, 136.

14 BG Davis, FG Synder, KE Elliott, PB Manzo, A Gaitenby, DA Larson, 'The First International Competition for Online Dispute Resolution: Is it Big, Different and New?' (2002) 19(4) Journal of International Arbitration 379.
} 
reached a level of 60 million resolved disputes a year some time ago. ${ }^{15}$ But generally, unless there is a settlement or voluntary compliance, the procedure does not bring relief. Settlements are sometimes criticized as a victory of the demands of individuals over the rule of law. In this sense it is a step back from law, a capitulation - not justice. ${ }^{16}$

As Melissa Tyler and Di Bretherton point out, the development of ODR has already undergone three stages: hobbyist, experimental, and entrepreneurial. ${ }^{17}$ In the first one there was no formal funding source. In the second, academics and NGOs took up the challenge. Finally, in the third, commercial undertakings began to develop and offer services on a broad basis. This evolution was accompanied by technological advances: from purely e-mail communication to sophisticated management systems.

According to Sami Kallel, Internet disputes fall into one of three major categories: a) disputes relating to infrastructure such as refusal of access on discriminatory grounds, b) information circulation such as privacy infringement, and c) contractual disputes. ${ }^{18}$ This third category is dominant. One should, however, keep in mind that ODR can equally apply to disputes completely unrelated to cyberspace. On the other hand a new kind of dispute has in cyberspace emerged: disputes originated in cyberspace with consequences arising outside of it. For instance, an unlawful act in multiplayer online role playing computer games which cause financial losses to the participants in the real world. ${ }^{19}$

It is unlikely that large international commercial transactions will be submitted to ODR, even though parties to disputes arising from such transactions will make use of technology improvements. But ODR may well serve the resolution of minor and medium-scale disputes. Furthermore, there is no reason to limit the application of ODR to e-commerce. ${ }^{20}$

In theory, all existing national and international arbitration laws apply to cyberspace. The problem is in determining how to apply and interpret them. ${ }^{21}$

\footnotetext{
${ }^{15}$ C. Rule, C. Nagarajan, 'Leveraging the Widsom of Crowds: The eBay Community Court and the Future of Online Dispute Resolution' (2010) ACResolution 4, 5; Del Duca, Rule, Loebl (n 3) 63.

${ }^{16}$ See O Fiss, 'Against Settlement' (1984) 93 Yale Law Review 1073.

${ }^{17}$ MC Tyler, D Bretherton, 'Online Alternative Dispute Resolution' (2003) 7 Vindobona Journal of International Commercial Law \& Arbitration 199.

${ }^{18}$ S Kallel 'Online Arbitration' (2008) 25(3) Journal of International Arbitration 345, 346.

${ }^{19}$ FG Lastowka, D Hunter, 'The Laws of Virtual Worlds' (2004) 92 California Law Review 1,71 .

${ }^{20}$ G Kaufmann-Kohler, 'Online Dispute Resolution and its Significance for International Commercial Arbitration', <http://www.lk-k.com/data/document/online-dispute-resolutionand-its-significance-for-international-commercial-arbitration-global.pdf $>\quad 437, \quad 455$, accessed 1 October 2015.

${ }^{21}$ R Hill, 'Will Cyberspace use Cybercourts?' (1997) International Commercial Litigation $31 \mathrm{ff}$.
} 


\section{Typical Pros ANd Cons}

One should bear in mind that there is no such thing as a perfect civil procedure. Nor is there any such thing as a perfect dispute settlement mechanism either. Of course we should strive to come as close to the ideal as possible, but we should be aware of the limits. Therefore, for ODR to be successful, it does not need to be flawless. It is enough if its pros significantly outweigh its cons.

Many authors have written about the pros and cons of the ODR. Some of them also recommend critical requirements for a successful system. For example, Patricia Galloway enumerates advantages of ODR such as that it is economically viable, efficient, fast and flexible, interaction is asynchronous, it is non-confrontational, communication is more reflective, it is convenient, it allows access to better neutrals (because distance is not an issue), it facilitates record-keeping, data archiving, document management and searching, and also provides a neutral forum (not somebody's office) ${ }^{22}$ She also lists disadvantages. Some of them seem legitimate - authenticity, confidentiality, prone to false testimony, obstacles in using expert testimony. Others are not convincing: miscommunication (no body language), less control from neutrals, problems with building rapport, enforceability (although she admits that it is no different from the enforcement of an arbitration award granted in traditional arbitration). ${ }^{23}$ She also considers some of the advantages to be disadvantages at the same time. For instance, rapid communication and archived communication in her view may cause more harm than good.

According to Sami Kallel, the strengths of ODR include efficiency, flexibility, speed, and low cost. ${ }^{24}$ On the other hand, the three major legal challenges of ODR include: 1. conclusion of the arbitration clause online, 2 . determination of the applicable law, and 3. enforcement of the arbitration award. ${ }^{25}$ He also identifies four major obstacles for ODR. They include: 1. confidentiality concerns, 2 . transparency concerns, 3 . evidence authenticity concerns, and 4. problems with language and terminology. ${ }^{26}$ This last argument seems off the mark, since cyberspace is more globalised than the real world and space for miscommunication or misinterpretation is smaller. However, the other three seem to be fair criticisms.

In the view of Gabrielle Kaufmann-Kohler, a successful ODR provider must obey five major principles: 1 . transparency (of procedural rules and outcomes), 2. accessibility (mostly absence of cost barriers), 3. independence (funding issues), 4. timeliness (speed), 5. fairness (equal treatment of the parties). ${ }^{27}$

\footnotetext{
${ }^{22}$ PD Galloway, 'Is Construction Arbitration ready for Online Dispute Resolution?' (2013) 30(2) The International Construction Law Review 215, 218-220.

${ }^{23}$ ibid 220-225.

${ }^{24}$ Kallel (n 18) 345.

25 ibid 352.

26 ibid.

${ }^{27}$ Kaufmann-Kohler (n 20) 450-451.
} 
Shekhar Kumar lists four major benefits of ODR: 1. drastic costs decrease, 2. negotiations quality increase (without emotions), 3. Speed, and 4. removal of symbolic detriments of face-to-face meetings. ${ }^{28}$ Among the disadvantages he enumerates are: 1. technological gap (unequal access to ODR), 2. due process concerns (procedural and substantive fairness), 3 . potential for miscommunication and 4 . difficulty with obtaining authority by the mediator/neutral. ${ }^{29}$ Kumar's recommendations for the development of ODR include: 1. using technological advances along with training in how to use them, 2. government involvement to regulate the sector, and 3. conducting empirical research on ODR. ${ }^{30}$ In his opinion, ODR should be run by private entities but regulated by the government. ${ }^{31}$

Ethan Katsh, the founder of the Online Ombuds Office ODR project, praises ODR for speed, flexibility, low cost, easy communication, and avoiding jurisdiction problems. ${ }^{32}$ Rachel Turner discusses the hurdles faced by ODR. She mentions a lack of trained experts, awareness of consumers, jurisdiction and choice of law issues, the potential for fraud, and privacy and confidentiality. ${ }^{33}$

To Lan Hang the primary advantages of ODR are: convenience, lowcost, legitimacy for online users and avoiding jurisdictional issues. ${ }^{34}$ Disadvantages include: loss of the human factor, lack of accessibility (hardware and software requirements), lack of confidentiality and security, and difficulties with enforcement of arbitral awards. ${ }^{35}$ In his view a successful ODR should be: 1. specifically designed for online users, 2. establishing trust (ensuring confidentiality and security), 3. less expensive than litigation and traditional arbitration, 4 . easy to use, 5 . convenient, 6 . less time consuming, and 7. establishing a presence in cyberspace communities. ${ }^{36}$

As a side note it is worth mentioning that some authors are concerned about developing countries having unequal access to ODR when compared to industrialized states, due to insufficient numbers of personal computers, Internet hosts, illiteracy, and a lack of awareness and computer skills. The obstacles are not only technological in nature, but also social and legal. ${ }^{37}$ While this is obviously true, it does not seem to be the most pressing problem of developing states. Besides, many of those who do not have access to ODR do not have convenient and affordable access to state courts either. However,

\footnotetext{
${ }^{28}$ S Kumar, 'Virtual Venues: Improving Online Dispute Resolution as an Alternative to Cost Intensive Litigation' (2009) 27(1) John Marshall Journal of Information Technology \& Privacy Law 81, 85-86.

${ }^{29}$ ibid 87-89.

${ }^{30}$ Ibid $90-93$.

31 ibid 94.

32 E Katsh, 'Bringing Online Dispute Resolution to Virtual Worlds: Creating Processes Through Code' (2004) 49 New York Law Review 271, 283.

33 Turner (n 11) 143-144.

${ }^{34}$ Hang (n 12) 854-857.

35 ibid 857-861.

36 ibid 862.

${ }^{37}$ MB Wahab, 'Online Dispute Resolution and Digital Inclusion: Challenging the Global Digital Divide'

$<$ http://www.mediate.com/Integrating/docs/ODR\%20and\%20Digital\%20Inclusion\%20-

$\% 20$ Mohamed\%20Abdel\%20Wahab.pdf> 4-11, accessed 1 October 2015.
} 
due to its low cost, ODR could be the best option for many disputes in developing countries. Even in industrialized countries, as Thomas Schultz remarks, due to the small value of most ODR disputes they are highly unlikely to be pursued in national courts (due to economic irrationality). Allegedly only one dispute in a million million at eBay eventually goes to court. ${ }^{38}$

As William Ewart Gladstone, the Prime Minister of the United Kingdom, famously said, justice delayed is justice denied. People, and especially business, increasingly value time over victory. In particular, Internet users are used to their actions generating instant results. When the pros and cons of ODR are discussed, the bottom line is that the most important advantage of ODR over traditional ADR and state court litigation is the speed of the procedure.

\section{Attempts to Date at Establishing a SuCCessful ODR}

Technology in ODR is so important that it is sometimes called the fourth party, in addition to the claimant, defendant, and neutral. ${ }^{39}$ There is a wide range of technologies involved, such as e-mail, web forums, instant messaging, chat rooms, video conferencing, mobile and smart phone technology, artificial legal intelligence, blogs, Voice over Internet protocol, avatars, social networking sites, Wikis, and web maps. ${ }^{40}$

Not only are various technologies employed within ODR. There are also various mechanisms for dispute resolution online such as mediation, arbitration, a combination thereof, and more innovative systems like online mock jury trials, blind bidding and automated negotiation assistance. Blind bidding, for instance, is a purely ODR creation, not known to traditional ADR. First the parties jointly determine the spread between which they agree to settle. Then they make offers without seeing the other party's offer. If they fit the spread, the case is settled. ${ }^{41}$

That's an amazing invention - but who would ever want to use one of them? said the president of the United States, Rutherford B. Hayes, after participating in a trial telephone conversation in 1876. This kind of approach towards new innovations such as ODR seems to apply today. One cannot deny that the advantages of online dispute resolution are far greater than its weaknesses, yet the world has so far failed to embrace the concept. The truth is, existing ODR providers are failing to attract Internet users. Almost all of the early projects suffer from the same weakness: lack of publicity. ${ }^{42}$

The first attempts to establish an ODR centre were made by universities. The Virtual Magistrate was created at Villanova University, the Cybertribunal (later eResolution) at the University of Montreal, and the

\footnotetext{
${ }^{38}$ Schultz (n 13) 137-138.

39 Katsh, 'Bringing Online Dispute Resolution' (n 32) 284-285; Katsh, 'Online Dispute Resolution' (n 4) 820; Galloway (32) 216; XU Junke, 'Development of ODR in China' $<$ https://law.pace.edu/lawschool/files/iicl/odr/Xu_Junke.pdf $>3$, accessed 1 October 2015.

${ }^{40}$ Galloway (n 39) 216-217.

${ }^{41}$ Kaufmann-Kohler (n 20) 438-439.

${ }^{42}$ Hang (n 12) 861.
} 
Resolution Forum at the South West Texas Law School. ${ }^{43}$ None of them exists today.

Some of the existing ODR systems are non-profit, while others are highly commercial. Some are automated, but most still require humans to resolve the dispute. Some focus on a particular kind of dispute (e.g. National Arbitration Forum and WIPO deal exclusively with Internet domain names disputes $^{44}$ ), others are universal. ${ }^{45}$

Two frequently-invoked successful ODR systems are eBay and ICANN solutions. In 1999 eBay began to cooperate with the Center for Information Technology and Dispute Resolution at the University of Massachusetts to conduct a pilot program on online disputes. A few months after the program, eBay selected SquareTrade as its ODR provider. Later on, eBay implemented its internal dispute resolution mechanism, which handles millions of disputes annually. Despite the fact that eBay does not charge its clients for using the ODR mechanism, it is considered as a pioneer in applying ODR in its commercial activity. ${ }^{46}$ Although it does not use Trustmark for its users, eBay has a very developed feedback system and reputation loss is enough of an incentive to guarantee compliance. ${ }^{47}$

The second example is the Internet Corporation for Assigned Names and Numbers (ICANN) Uniform Dispute Resolution Policy (UDRP) on Internet domain names disputes. ${ }^{48}$ It is designed to solve the problem of cybersquatting, which means purchasing Internet domains of registered trademarks. The system does not award compensation, but is self-enforceable by assigning domains to the winning parties. ICANN does not resolve disputes itself. It accredits existing ODR providers (currently five in the world). ${ }^{49}$

Both of the above-mentioned successful ODR systems have limited application. The first one deals only with eBay disputes, which are simple, low value, consumer-related, e-commerce deals. ICANN-approved ODR providers handle only domain name disputes. Louis Del Duca, Colin Rule (eBay ODR director for almost a decade) and Zbynek Loebl have proposed a universal, global ODR system. It is a purely theoretical work and so far exists only on paper, but one must admit that its architecture has been designed in great detail and includes a variety of stakeholders. They combined strengths of the following ODRs: eBay, ICANN, Better Business Bureaus in the United States and Canada, Concilianet in Mexico, Organization of American States, and many others. ${ }^{50}$ For now this project remains entirely on paper.

Unlike at the national level, some international organizations have undertaken legislative initiatives in the field of ODR. Since 2012,

\footnotetext{
${ }^{43}$ E Katsh, 'The New Frontier. Online ADR becoming a global priority' (2000) Dispute Resolution Magazine 6.

${ }^{44}$ The complete list of Internet domain names disputes resolution providers is available at $<$ https://www.icann.org/resources/pages/providers-6d-2012-02-25-en> 1 October 2015.

${ }^{45}$ Katsh, 'The New Frontier' (n 43) 6.

${ }^{46}$ Katsh, 'Bringing Online Dispute Resolution' (n 32) 277-279.

${ }^{47}$ Del Duca, Rule, Loebl (n 3) 64.

${ }^{48}$ Katsh, 'Bringing Online Dispute Resolution' (n 32) 279-280.

${ }^{49}$ See footnote 44.

${ }^{50}$ Del Duca, Rule, Loebl (n 3) 63-74.
} 
UNCITRAL Working Group III has been engaged in work on an ODR model law. It is an interesting project, but it will probably take much time before it is ready. It must also be noted that the procedure is designed exclusively for e-commerce, transnational, low value disputes. ${ }^{51}$ The European Union has also engaged in a legislative effort to enhance the development of ODR. Also in this case the focus is only on e-commerce consumer disputes. ${ }^{52}$

Not everyone is pleased with the legislative initiatives mentioned above. Some authors have expressed the opinion that ODR systems should develop on their own without interference from state authorities. ${ }^{53}$

\section{CHALLENGES FOR ODR SYSTEMS}

In order for an arbitration award to be enforceable, the ODR procedure must guarantee due process. ${ }^{54}$ One of the challenges is authentication, which is more difficult in cyberspace than in the "real world". It encompasses any method of verifying a piece of information in an electronic environment: its integrity, the identity of the author, and that it has been transmitted in its entirety. ${ }^{55}$ The first problem is of a purely legal nature, namely, whether an arbitration agreement and arbitration award not in writing are valid. This depends on the applicable national law. For example, in Poland an arbitration agreement does not need to be in writing ${ }^{56}$, but the award needs to be printed and signed by an arbiter ${ }^{57}$, unless he signs it using an electronic signature. ${ }^{58}$ According to the NY Convention ${ }^{59}$ an arbitration agreement should be in writing, which includes an arbitral clause in a contract or an arbitration agreement, signed by the parties or contained in an exchange of letters or telegrams. ${ }^{60}$ However, in the view of the majority of experts, this should be interpreted as encompassing modern means of electronic communication. ${ }^{61}$

\footnotetext{
${ }^{51}$ V Rogers, 'Managing Disputes in the Online Global Marketplace. Reviewing the Progress of UNCITRAL's Working Group III on ODR' (2013) Dispute Resolution Magazine 20.

${ }^{52}$ Regulation (EU) No 524/2013 of the European Parliament and of the Council of 21 May 2013 on online dispute resolution for consumer disputes and amending Regulation (EC) No 2006/2004 and Directive 2009/22/EC (Regulation on consumer ODR) [2013] OJ L165/1.

${ }^{53}$ Hang (n 12) 863.

54 E.g., Article 1183 of the Polish Civil Procedure Code requires arbitration to guarantee equal treatment of the parties and opportunity to present evidence and arguments.

${ }_{55}^{55}$ Haloush (n 12) 356-357.

${ }^{56}$ Polish Civil Procedure Code, Article 1162(2).

${ }^{57}$ Polish Civil Procedure Code, Article 1197(1).

${ }^{58}$ Polish Electronic Signature Act, Article 5(2).

${ }^{59}$ Convention on the Recognition and Enforcement of Foreign Arbitral Awards, also known as the New York Convention, adopted by a United Nations diplomatic conference on 10 June 1958 and entered into force on 7 June 1959, 330 UNTS 38; 21 UST 2517; 7 ILM 1046 (1968). ${ }^{60}$ Article 2(1) and 2(2).

${ }^{61}$ E.g., Haloush (n 12) 363; D Szostek, M Świerczyński, ‘Arbitraż elektroniczny’ (2006) 16 Monitor Prawniczy 1, 6-7; S Halla, 'Arbitration Going Online - New Challenges in 21st Century?’ <https://journals.muni.cz/mujlt/article/view/2583/2147>217, 221-224, accessed 1 October 2015; J Balcarczyk, 'Zagadnienie formy umowy o arbitraż w świetle art. II (2) Konwencji nowojorskiej o uznawaniu i wykonywaniu zagranicznych orzeczeń arbitrażowych oraz w świetle regulacji wewnętrznych', $<$ http://arbitraz.laszczuk.pl/ adr/49/Zagadnienie formy umowy o arbitraz w swietle art. II 2 Konwencji nowojorskiej o uznawaniu i wykonywaniu zagranicznych orzecze

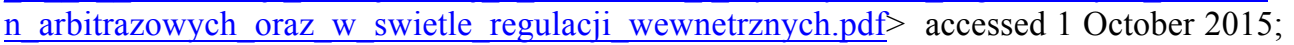


Also, EU legislation ${ }^{62}$, the UNICTRAL Model Law on Electronic Commerce $^{63}$ and the UNCITRAL Model Law on International Commercial Arbitration ${ }^{64}$ recognize the validity of electronic contracts without electronic signatures. There are still problems of a technical nature, such as verification of the identity of a party which does not use an electronic signature, or authenticity of evidence provided online. These can be dealt with in a variety of ways, for example by submitting a scanned ID or by making a payment from a personal bank account which has been verified by a bank.

The problem of jurisdiction does not exist in ADR or ODR. It may only be of relevance in enforcement proceedings, whether an award was granted in the state of enforcement or outside of it. This is because sometimes different rules apply to those awards, such as due to obligations under the New York Convention.

Choice of law can be dealt with quite easily. Since an arbitration agreement is necessary to submit a dispute to ADR or ODR, there is no problem to include choice of applicable law in such an agreement. Furthermore, it is suggested that with time the body of customary rules applied in cyberspace will evolve into lex electronicae or lex cybesneticae (analogous to lex mercatoria). ${ }^{65}$ It could develop from current customary practices of Internet users' behaviour, commonly known as netiquette (combining words "Internet" and "etiquette"). ${ }^{66}$

Another reason for the lack of attractiveness of ODR may be enforcement issues. Unfortunately, to become enforceable, arbitral awards require reference to state courts. This means a return to the paper form and geographical limitations. For this reason some authors suggest other means of enforcement which include: a) money methods (financial guarantees, escrow accounts, charge-back agreements with credit card companies or some kind of judgement fund), b) technical control methods (like in the UDRP procedure for domain names, where domains are simply transferred or cancelled regardless of the consent of the losing party), c) reputation methods (trustmarks). ${ }^{67}$ None of these solutions seems easy to implement.

The problems with ODR systems are not only legal, but also technological. One should realize that as long as disputes resolved online are of a simple nature, the software should be simple as well. But if the dispute is complex and multifaceted, the software must be equally sophisticated. Development of quality software is expensive ${ }^{68}$ and time consuming ${ }^{69}$,

also Polish Supreme Court supported this view in Decision of 23 January 2013, I CSK $186 / 12$.

${ }^{62}$ Directive 2000/31/EC of the European Parliament and of the Council of 8 June 2000 on certain legal aspects of information society services, in particular electronic commerce, in the Internal Market (Directive on electronic commerce) [2000] OJ L 178/1, Articles 9(1) and $17(1)$.

63 Adopted on 12 June 1996, Article 8.

${ }^{64}$ Adopted on 11 December 1985, Article 7(2).

${ }^{65}$ Kallel (n 18) 852.

${ }^{66}$ Hang (n 12) 839.

${ }^{67}$ Kaufmann-Kohler (n 20) 454.

68 ibid 452.

${ }^{69}$ Katsh, 'Bringing Online Dispute Resolution' (n 32) 286. 
therefore the supply of such ODR services is limited. Such investment is largely dependent on how complex the interactions between the participants should be. For this reason some authors suggest that a successful mediation system is more costly than an arbitration system. ${ }^{70}$ An example of technological limitations are videoconferences, which require particular hardware (camera, microphone), software (compatible with different operating systems), Internet connection (data transfer) and servers (data storage).

\section{CONCLUSION}

The advantages of ODR seem to considerably outweigh the disadvantages. Obviously it is supply and demand that will dictate the growth ofODR. The concept of ODR is over 15 years old now and can no longer be considered a novelty. But, as Rachel Turner put it, we are on the brink of an online revolution. ${ }^{71}$ There are willing participants, willing clients, moneymaking potential, and the software is being improved every day. ODR should not simply duplicate traditional arbitration, but rather maximize the power of technology. It is also important to ensure proper training and education in order to minimize the risk of failure.

This is just the beginning - ODR will become an industry in its own right. It is destined to succeed sooner or later. For that reason, Ethan Katsh suggests that in the future it will be called not ODR but PDR (primary dispute resolution). ${ }^{72}$ Jeffrey Scott Wolfe already understands ADR not as alternative dispute resolution, but as appropriate dispute resolution. ${ }^{73}$

\section{References}

Balcarczyk J, ‘Zagadnienie formy umowy o arbitraż w świetle art. II (2) Konwencji nowojorskiej o uznawaniu i wykonywaniu zagranicznych orzeczeń arbitrażowych oraz w świetle regulacji wewnętrznych', $<$ http://arbitraz.laszczuk.pl/_adr/49/Zagadnienie formy umowy o arbitraz w swietle art. II 2 Konwencji nowojorskiej o uznawaniu i wykony waniu zagranicznych orzeczen arbitrazowych oraz $w$ swietle regulacji wewnetrznych.pdf $>$.

Berners-Lee T, Fischetti M, Weaving the Web: the Original Design and Ultimate Destiny of the World Wide Web (San Fransisco 1999).

Davis BG, Synder FG, Elliott KE, Manzo PB, Gaitenby A, Larson DA, 'The First International Competition for Online Dispute Resolution: Is it Big, Different and New?' (2002) 19(4) Journal of International Arbitration.

\footnotetext{
${ }^{70}$ Haloush (n 12) 818.

${ }^{71}$ RI Turner (n 11) 148.

${ }^{72}$ E. Katsh, 'The New Frontier (n 43) 6.

73 JS Wolfe, 'Symposium: Alternative Dispute Resolution In the Twenty-First Century: Across the Ripple of Time: The Future of Alternative (or, is it “Appropriate?") Dispute Resolution' (2001) 36 Tulsa Law Journal 785.
} 
Del Duca L, Rule C, Loebl Z, 'Facilitating Expansion of Cross-Border ECommerce - Developing Global Online Dospute Resolution System (Lessons Derived from Existing ODF Systems - Work of the United Nations Commission on International Trade Law)' (2012) 1(1) Penn State Journal of Law \& International Affairs.

Fiss O, 'Against Settlement' (1984) 93 Yale Law Review.

Geist MA, 'The Reality Bytes: Regulating Economic Activity in the Age of the Internet' (1998) 73 Washington Law Review.

Halla S, 'Arbitration Going Online - New Challenges in 21st Century?' https://journals.muni.cz/mujlt/article/view/2583/2147.

Haloush HA , 'The Authenticity of Online Alternative Dispute Resolution Proceedings' (2008) 25(3) Journal of International Arbitration.

Hang LQ, 'Online Dispute Resolution Systems: The Future of Cyberspace Law' (2001) 41(3) Santa Clara Law Review.

Hill R, 'Will Cyberspace use Cybercourts?' (1997) International Commercial Litigation. Galloway PD, 'Is Construction Arbitration ready for Online Dispute Resolution?' (2013) 30(2) The International Construction Law Review.

Junke XU, 'Development of ODR in China' $<$ https://law.pace.edu/lawschool/files/iicl/odr/Xu_Junke.pdf $>$.

Kallel S, 'Online Arbitration' (2008) 25(3) Journal of International Arbitration.

Katsh E, 'Bringing Online Dispute Resolution to Virtual Worlds: Creating Processes Through Code' (2004) 49 New York Law Review.

Katsh E, 'Online Dispute Resolution: Some Lesson from the E-Commerce Revolution' (2001) 28(4) Northern Kentucky Law Review.

Katsh E, 'The New Frontier. Online ADR becoming a global priority' (2000) Dispute Resolution Magazine.

Kaufmann-Kohler G, 'Online Dispute Resolution and its Significance for International Commercial Arbitration', <http://www.lk$\mathrm{k} . c o m /$ data/document/online-dispute-resolution-and-its-significance-forinternational-commercial-arbitration-global.pdf $>$

Kesna JP, Shah RC, 'Fool us once shame on you - fool us twice shame on us: what we can learn from the Privatisations of the Internet Backbone Network and the Domain Name System' (1994) 79(1) Washington University Law Quarterly.

Kumar S, 'Virtual Venues: Improving Online Dispute Resolution as an Alternative to Cost Intensive Litigation' (2009) 27(1) John Marshall Journal of Information Technology \& Privacy Law.

Lastowka FG , Hunter D, 'The Laws of Virtual Worlds' (2004) 92 California Law Review.

Rogers V, 'Managing Disputes in the Online Global Marketplace. Reviewing the Progress of UNCITRAL's Working Group III on ODR' (2013) Dispute Resolution Magazine.

Rule C, Nagarajan C, 'Leveraging the Widsom of Crowds: The eBay Community Court and the Future of Online Dispute Resolution' (2010) ACResolution. 
Schultz T, 'The Role of Dispute Settlement and ODR' in A Ingez-Housz, ADR in Business: Practice and Issues across Countries and Cultures, vol. II (Bedfordshire 2011).

Szostek D, Świerczyński M, ‘Arbitraż elektroniczny’ (2006) 16 Monitor Prawniczy.

Turner RI, 'Alternative Dispute Resolution in Cyberspace: there is more on the line than just getting "online"' (2000) 7 ILSA Journal of International \& Comparative Law.

Tyler MC, Bretherton D, 'Online Alternative Dispute Resolution' (2003) 7 Vindobona Journal of International Commercial Law \& Arbitration.

Wahab MB, 'Online Dispute Resolution and Digital Inclusion: Challenging the Global Digital Divide' $<$ http://www.mediate.com/Integrating/docs/ODR\%20and\%20Digital\%20Inc lusion\%20-\%20Mohamed\%20Abdel\%20Wahab.pdf $>$.

Weinstein JB , 'Some Benefits and Risks of Privatization of Justice Through ADR' (1996) 11 Ohio State Journal on Dispute Resolution.

Wolfe JS, 'Symposium: Alternative Dispute Resolution In the TwentyFirst Century: Across the Ripple of Time: The Future of Alternative (or, is it “Appropriate?”) Dispute Resolution' (2001) 36 Tulsa Law Journal. 